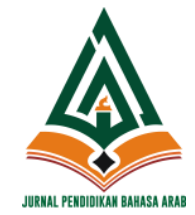

\author{
Alibbaa': Jurnal Pendidikan Bahasa Arab \\ Vol. 3 No. 1, January 2022 \\ P-ISSN: 2721-1606 | E-ISSN: 2716-4985 \\ doi: https://doi.org/10.19105/ajpba.v3i1.5474
}

\title{
Pembelajaran Naḥwu-Ṣarf di Pesantren dengan Pendekatan Interpretatif: Implikasi Teori Interpretasi Jorge JE Gracia dalam Pembelajaran Kitab Alfiyyah Ibn Mālik
}

\author{
Habib Maulana Maslahul Adi, Nur Romdlon Maslahul Adi \\ State Islamic University of Sunan Kalijaga Yogyakarta, Indonesia \\ State Islamic University of Sunan Ampel Surabaya, Indonesia \\ Corresponding E-mail: maslabulhabib@gmail.com
}

\begin{abstract}
This study aims to reveal and describe the reasons, processes, and implications of learning Nahwu-Sarf from the book Alfiyyah Ibn Mālik with interpretive approach at Pondok Pesantren Al-Luqmaniyyah Yogyakarta. This study used a qualitative approach, where data were obtained through observation, interviews, and documentation techniques. Data analysis was carried out by reducing, interpreting, presenting, and drawing conclusions. Data testing is done through triangulation. The results of the study show that: (1) The reasons for practicing interpretive learning are because textual understanding of nazm is the main paradigm of learning, as well as the content behind the textual meaning that is intriguing; (2) the process involves extracting the original meaning of the text, the original meaning intended by the author, extracting the implicit meaning behind textual understanding, and relating it to other things; and (3) It has implications for increasing the students' interest in learning participation, as well as inculcating the knowledge values to students' life.
\end{abstract}

Keywords: Cooperative Learning, Arabic language, Application. 


\section{Pendahuluan}

Proses transfer ilmu Naḥwu-Ṣarf yang kajiannya hanya dibatasi secara tekstual saja, tanpa adanya upaya lebih lanjut berupa kontekstualisasi pemahaman akan ilmu Naḥwu- Șarf merupakan salah satu permasalahan yang dihadapi oleh lembaga pendidikan pesantren. Mengingat ilmu Nahwwu-Ṣarf apabila dianalisis secara teks maupun konsep, tak jarang ditemukan nilai-nilai yang terkandung di dalamnya, seperti nilai pendidikan ${ }^{1}$, nilai etika ${ }^{2}$, nilai akhlak $^{3}$, nilai tasawuf ${ }^{4}$, nilai karakter ${ }^{5}$, dan nilai-nilai yang lainnya.

Melihat khazanah keilmuan ulama terdahulu, upaya untuk mengkontekstualisasikan pemahaman atas ilmu Naḥwu-Șarf pernah digaungkan oleh 'Abd al-Qādir al-Kūhani $(1254 \mathrm{H})$, yang membahas aspek tasawuf dalam ilmu Naḥwu dengan karakter akhlāqī- $a m a l{ }^{6}$ lewat kitab Munyah al-Faqīr al-Mutajarrid wa Sīrah al-Murīd alMutafarrid. $^{7}$ Bahkan jauh sebelum itu juga sudah dicontohkan oleh

\footnotetext{
${ }^{1}$ Fatkhiyyaa Izza Khunainatuz and Hilyah Ashoumi, “Analisis Nilai-Nilai Pendidikan Islam Yang Terkandung Dalam Makna Tersirat Nadzam Alfiyah Ibnu Malik Dan Aktualisasinya Pada Konteks Pendidikan Islam Modern," Jurnal Ilmu Pendidikan Islam, Vol. 16 No. 1, 2020: 1-14.

https://jurnal.staidagresik.ac.id/index.php/attaqwa/article/view/33

${ }^{2}$ Gufron, Arif Mustofa, and Abdullah Zainur Rauf, "Interpretasi Dan Aktualisasi

Nilai-Nilai Etika Nadham Alfiyah Ibnu Malik Dalam Kehidupan Sosial (Pendekatan Obyektif Pragmatik)," Arabia: Jurnal Pendidikan Bahasa Arab, Vol. 12 No. 1, 2020: 54-73. https://journal.iainkudus.ac.id/index.php/Arabia/article/view/7439

${ }^{3}$ Afandi and Moh. Lutfi, "Membumikan Nilai-Nilai Akhlak Dalam Kitab Al-Fiyah Ibnu Malik Di Pondok Pesantren Roudlatul Mutaallimin Al Aziziyah II Sebaneh Bancaran Bangkalan," Attaqwa: Jurnal Ilmu Pendidikan Islam, Vol. 17 No. 2, 2021: 164-181. https://jurnal.staidagresik.ac.id/index.php/attaqwa/article/view/157

${ }^{4}$ Rizki Fathul Huda, Iik Arifin Mansurnoor, and Andi M. Faisal Bakti, "The Concept of Sufi I'rab by Abdul Qadir Al-Kuhany in Understanding the Salat Movement," in Proceedings of the 2nd International Colloquium on Interdisciplinary Islamic Studies (ICIIS) in Conjunction with the 3rd International Conference on Quran and Hadith Studies (ICONQUHAS) (Bratislava: EAI, 2020). https://eudl.eu/doi/10.4108/eai.7-112019.2294532

${ }^{5}$ Adi Supardi, "Nilai-Nilai Karakter Pengguna Bahasa Arab Perspektif I'rab Nahwu," Kalamuna: Jurnal Pendidikan Bahasa Arab dan Kebahasaaraban, Vol. 2 No. 1, 2021: 37-49. https://e-jurnal.staimuttaqien.ac.id/index.php/kalamuna/article/view/123 ${ }^{6}$ Mujahadah, "Dimensi Sufistik Dalam Ilmu Nahwu: Studi Komparatif Antara Kitab Nahwu Al-Qulub Karya Al-Qusyairi Dan Munyah Al-Faqir Al-Mutajarrid Wa Sirah Al-Murid Al-Mutafarrid Karya Al-Kuhany" (Universitas Islam Negeri Antasari, 2021), http://idr.uin-antasari.ac.id/16938/.

${ }^{7}$ Abd al-Qādir Al-Kūhani, Munyah Al-Faq̄̄r Al-Mutajarrid Wa Sīrah Al-Murīd AlMutafarrid (Aleppo: Dār al-Ḥayāh, n.d.), 6.
} 
Imām al-Qusyairī, seorang cendekiawan dan theoligian Muslim Arab (w. $465 \mathrm{H}$ ). ${ }^{8}$ Melalui kitabnya yang berjudul Naḥwu al-Qulūb, beliau menginterpretasikan dan melakukan pemaknaan kontekstual terhadap ilmu Nahwu dan mengaitkannya dengan disiplin tasawuf. ${ }^{9}$

Sebagai contoh, Imām al-Qusyairī menjelaskan bahwa pembahasan i'rāb yang terdapat dalam ilmu Nahwu sejatinya bisa dikaitkan pembahasannya dengan keadaan hati seorang hamba Allah Swt. Misalnya ialah i'rāb al-raf'u yang beliau artikan sebagai bersihnya hati dari perkara dunia (raf'u al-qulūb 'an al-dunyā), yang mana pemilik sifat tersebut dalam ilmu tasawuf disebut sebagai zāhid (plural: $z u h h \bar{a} d$ ). Selain itu juga beliau artikan sebagai bersihnya hati dari keinginan kuat untuk mengikuti syahwat (raf'u al-qulüb 'an alsyahawāt) supaya layak berposisi sebagai seorang hamba atau 'âbid (plural: 'ubbād). Contoh lain, ketika beliau menafsirkan $i$ 'rāb al- khafd sebagai sifat rendah hati (khaf̣d al-qulüb). Sifat rendah hati (altawā $u^{\prime}$ ') yang merupakan ajaran tasawuf itu bisa diwujudkan dengan tumbuhnya rasa malu, upaya untuk menjaga harga diri (murūah), selalu merasa rendah, dan merelakan diri dalam meninggikan kalimah Allah Swt. ${ }^{10}$

Sebagaimana yang dilakukan oleh Al-Qusyairī dan Al-Kūhani, upaya demikian juga dilakukan oleh ulama dari Yogyakarta, Indonesia, yakni Kiai Nur Iman Mlangi. Bahkan Zakiyah menyebut bahwa upaya Kiai Nur Iman sedikit lebih dulu dari lahirnya karya 'Abd al-Qādir alKūhani di atas. ${ }^{11}$ Menurut Irwan Masduqi, meski Kiai Nur Iman memberikan pemaknaan tasawuf dengan pendekatan sufistik terhadap teori ilmu Nahwu, kitab Al-San̄̄ al-Mațālib fī al-Ișțilāḥ al-'Awāqib karya beliau itu tetap memuat makna aslinya terkait tata bahasa Arab. ${ }^{12}$

\footnotetext{
${ }^{8}$ Abd al-Karīm ibn Hauzan ibn 'Abd al-Mālik ibn Ṭalḥah ibn Muhammad Abū alQāsim Al-Qusyairī, Naḥwu Al-Qulūb (Beirut: Dār al-Kutub al-'Ilmiyyah, 2005), 5; Umar Riḍā Kaḥālah, Mu’jam Al-Muallifinn (Beirut: Muassasaḥ al-Risālah, 1993), 212.

${ }^{9}$ Shahrizal Mahpol, Muhammad Saiful Anuar Yusoff, and Muhammad Luqman Ibnul Hakim, "Nilai Kerohanian Dalam Disiplin Ilmu Nahu; Kajian Terhadap Sumbangan Al-Qushayri," INSANIAH: Online Journal of Language, Communication, and Humanities, Vol. 3 No. 1, 2020: 12-25.

http://insaniah.umk.edu.my/journal/index.php/insaniah/article/view/68

${ }^{10}$ Nahwu Al-Qulüb, 9-10.

${ }^{11}$ Zakiyah, "Kitab Al-Sanī Al-Mațālib: Interkoneksi Nahwu Dan Tasawuf,"

Walisongo: Jurnal Penelitian Sosial Keagamaan, Vol. 20 No. 2, 2012: 371-390. https://journal.walisongo.ac.id/index.php/walisongo/article/view/204

${ }^{12}$ Irwan Masduqi, Suluk Sufi Ulama Karaton Yogyakarta: Ajaran Kyai Nur Iman (Yogyakarta: Assalafiyah Press, 2011), 83-84.
} 
Buah pemikiran Kiai Nur Iman dalam mengajarkan ilmu Nạ̣wu dan menghubungkannya dengan kajian tasawuf jelas terasa tatkala beliau membahas bab Id $\bar{a} f a h$. Apabila ulama Nahwu memaknai I $d \bar{a} f a h$ ialah persandaran dua kata atau lebih, ada yang disandarkan (al-mudquf) dan ada yang disandari (al-mudāf ilaih). Kiai Nur Iman menambahkan catatan terkait pembahasan ini, bahwasanya Iḍaffah ialah penyandaran diri seorang hamba kepada Zat Yang Menciptakannya, yakni Allah Swt. ${ }^{13}$

Uraian di atas merupakan petunjuk akan adanya peluang untuk menginterpretasikan ilmu Naḥwu-Ṣarf, bahkan prosesnya mungkin juga dapat diimplementasikan dalam pembelajaran dalam rangka memberikan pengetahuan tambahan kepada para santri. Sekaligus dapat dijadikan sebagai upaya menjaga dan mencontoh tradisi yang telah dilakukan oleh ulama terdahulu. Di sinilah posisi pesantren yang harus menjaga dan meneruskan pengembangan keilmuan sebagaimana yang telah dilakukan ulama. Sehingga penting kiranya bagi pesantren dan seluruh unsur yang ada di dalamnya untuk selalu melahirkan inovasi demi kelangsungan perkembangan ilmu pengetahuan keislaman, khususnya pada pembelajaran Nạ̣wu-Ṣarf.

Teori yang bisa diterapkan dalam proses interpretasi ini misalnya ialah teori fungsi intrepretasi (interpreter's function) yang dikemukakan oleh Jorge JE Gracia, profesor filsafat dari University of Buffalo New York. Interpretasi di sini memiliki tiga pengartian, yakni: (1) interpretasi sama dengan pemahaman (understanding). Maksudnya adalah interpretasi digunakan sebagai satu bentuk pemahaman yang dimiliki seseorang terhadap makna teks; dan (2) interpetasi diartikan sebagai suatu proses atau akivitas seseorang dalam mengembangkan pemahaman terhadap teks. Dalam hal ini, interpretasi melibatkan pengkodean (decoding) terhadap teks supaya pesan dalam teks dapat dipahami; serta (3) interpretasi yang digunakan untuk merujuk pada kajian tentang teks. ${ }^{14}$

Interpretasi Gracia secara umum terbagi menjadi dua bagian, yaitu interpretasi tekstual dan interpretasi nontekstual. Sedangkan sebuah interpretasi dapat digolongkan sebagai interpretasi tektual atau

\footnotetext{
${ }^{13}$ Nur Iman, Al-Sunī Al-Mațālib Fī Al-Iștilāḥ Al- 'Awāqib, n.d., 21.

${ }^{14}$ Syafa'atun Al-Mirzanah and Sahiron Syamsuddin, eds., Pemikiran Hermeneutika Dalam Tradisi Barat: Reader (Yogyakarta: Lembaga Penelitian UIN Sunan Kalijaga, 2011), 148.
} 
nontekstual itu tergantung pada tujuan interpretasi tersebut. ${ }^{15}$ Menimbang bahwasanya interpretasi yang merupakan "hati" dari hermeneutika dapat diimplementasikan dalam pendidikan ${ }^{16}$, maka dalam penelitian ini teori interpretasi Jorge JE Gracia dijadikan pisau analisis.

Penelitian tentang interpretasi dari teks Naḥwu-Șarf memang bukan pertama kali dilakukan, karena dijumpai beberapa penelitian relevan yang dilakukan oleh peneliti sebelumnya. Misalnya ialah penelitian Khoiriyah yang mengkaji tentang nilai karakter dalam syarh Alfiyyah Ibn 'Aqil karya Imam al-Suyūṭi berikut relevansinya dengan pendidikan Akhlak yang dianalisis dari segi hermeneutik. ${ }^{17}$ Kemudian penelitian Afandi dan Hakim tentang interpretasi makna pada istilah Naḥwu yang mengkaji kaitan antara Nahwwu dengan tasawuf. ${ }^{18}$ Selain itu, penelitian Maulana tentang kajian terhadap kitab Nạ̣wu al-Qulūb karya Al-Qusyairī yang menginterpretasikan Naḥwu ke dalam kajian tasawuf. ${ }^{19}$

Penelitian yang telah disebutkan di atas secara umum memang membahas tentang pemaknaan atau interpretasi terhadap ilmu Naḥwu, akan tetapi terbatas pada kajian terhadap materinya saja dan belum menjangkau pada pengaplikasiannya dalam proses pembelajaran. Oleh karenanya, dapat dimengerti bahwa terdapat celah yang perlu untuk diisi supaya dapat menyempurnakan penelitian-penelitian sebelumnya.

${ }^{15}$ Sahiron Syamsuddin, Hermeneutika Dan Pengembangan Ulumul Qur'an (Yogyakarta: Pesantren Nawasea Press, 2017), 114; Ulummudin, "Hadith on the Prohibition of Woman Traveling without a Mahram (Application of Hermeneutic Theory of Jorge J. E. Gracia)," Asliha-Islamicate Institute: Journal of Hadith Studies, Vol. 1 No. 1, 2018: 29-30.

https://journal.islamicateinstitute.co.id/index.php/johs/article/view/361

${ }^{16}$ Sembodo Ardi Widodo, "Metode Hermeneutik Dalam Pendidikan," in Antologi Pendidikan Islam, ed. Nizar Ali and Sumedi, vol. 31 (Yogyakarta: Idea Press, 2010), 109.

${ }^{17}$ Miftah Sa'adatul Khoiriyah, "Nilai-Nilai Karakter Dalam Syarah Alfiyyah Ibn 'Aqil Karya Imam Al Alamah Syeikh Jalaluddin As-Suyuthi Dan Relevansinya Dengan Pendidikan Akhlak (Analisis Hermeneutik)" (Institut Agama Islam Negeri Ponorogo, 2020).

${ }^{18}$ Zamzam Afandi and Arief Rahman Hakim, "Al-Takwīl Al-Bāṭinī Li Musțalahāt anNahwi (Takamul Al-Tasawwuf Wa Al-Nahwi)," LiNGUA: Jurnal Ilmu Bahasa dan Sastra, Vol. 16 No. 1, 2021: 99-110. https://ejournal.uinmalang.ac.id/index.php/humbud/article/view/12242

${ }^{19}$ Muhammad Iqbal Maulana, "Refleksi Sufistik Dalam Nahwu Al-Qulub Karya Abu Al-Qasim Al-Qusyairi,” Dialogia: Jurnal Studi Islam dan Sosial, Vol. 17 No. 1, 2019: 21-40. https://jurnal.iainponorogo.ac.id/index.php/dialogia/article/view/1654 
Sehingga penelitian ini difokuskan untuk mengkaji pengaplikasian pendekatan interpretatif pada proses pembelajaran, yang meliputi alasan, proses, faktor pendukung dan penghambat, serta implikasinya dalam pembelajaran Naḥwu-Ṣarf.

Berdasar uraian di atas, maka tujuan dari penelitian ini ialah mengungkap dan mendeskripsikan alasan pengimplementasian pendekatan interpretatif, proses pengimplementasian, faktor pendukung dan penghambat, serta implikasi dari diimplementasikannya pendekatan interpretatif dalam pembelajaran Naḥwu-Șarf kitab Alfiyyah Ibn Mālik di Pondok Pesantren Al-Luqmaniyyah Yogyakarta.

\section{Metode Penelitian}

Pendekatan yang digunakan dalam penelitian ini ialah pendekatan kualitatif, karena penelitian ini bertujuan untuk mengungkap dan mendeskripsikan alasan, proses, dan implikasi dari pengimplementasian pendekatan interpretatif dalam pembelajaran Naḥwu-Ṣarf kitab Alfiyyah Ibn Mālik di Pondok Pesantren AlLuqmaniyyah Yogyakarta. ${ }^{20}$ Dipilihnya Pondok Pesantren AlLuqmaniyyah sebagai subjek penelitian ini karena berdasar studi prapenelitian diketahui bahwasanya pesantren tersebut menerapkan pendekatan interpretatif dalam pembelajaran Naḥwu-Ṣarf kitab Alfiyyah Ibn Mālik.

Penelitian ini melibatkan data primer dan data sekunder. Sumber data primernya ialah ketua Dewan Pendidikan Pondok Pesantren AlLuqmaniyyah, pengampu kitab Alfiyyah Ibn Mālik, serta para santri kelas Alfiyyah Pondok Pesantren Al-Luqmaniyyah Yogyakarta, yang diperoleh di lapangan melalui observasi, wawancara dan dokumentasi. Sedangkan data sekunder atau data pendukungnya ialah sumber literatur berupa buku maupun artikel jurnal yang diperoleh melalui penelusuran literatur, baik offline maupun online.

Data diperoleh melalui tiga teknik, yaitu: (1) Observasi langsung, untuk memperoleh gambaran sebenarnya dari proses pengimplementasian pembelajaran Nạ̣wu-Șarf kitab Alfiyyah Ibn Mālik dengan pendekatan interpretatif di Pondok Pesantren AlLuqmaniyyah Yogyakarta; (2) wawancara mendalam dan cermat terhadap informan, untuk memperoleh informasi dan penjelasan secara

\footnotetext{
${ }^{20}$ Nana Syaodih Sukmadinata, Metode Penelitian Pendidikan (Bandung: PT Remaja Rosdakarya, 2007), 60.
} 
detail terkait alasan, proses, dan implikasi penerapan pendekatan interpretatif dalam pembelajaran Naḥwu-Ṣarf kitab Alfiyyah Ibn Mālik di Pondok Pesantren Al-Luqmaniyyah; serta (3) studi dokumentasi, untuk memperoleh data terkait profil lembaga, kurikulum, keadaan santri, dan hal-hal lain yang relevan.

Setelah data diperoleh, maka dilakukan reduksi untuk memilih data yang relevan, kemudian diinterpretasikan dan disajikan dalam bentuk kata-kata. Demi menjamin keabsahan data, dilakukan triangulasi sumber dengan cara membandingkan hasil wawancara pada informan berbeda dengan pertanyaan sama. Apabila hasilnya sama, proses elaborasi data dihentikan. Selanjutnya dilakukan penafsiran data sebelum ditarik kesimpulan

\section{Hasil dan Pembahasan}

\section{Alasan Pengimplementasian Pendekatan Interpretatif}

Diimplementasikannya pendekatan interpretatif dalam pembelajaran Naḥwu-Ṣarf di Pondok Pesantren Al-Luqmaniyyah tentu bukan tanpa alasan. Menurut Ustaz Fairuz, pengajar Alfiyyah Ibn Mālik di Pondok Pesantren Al-Luqmaniyyah, di antara alasan yang dimaksud ialah terletak pada keunikan atau kelebihan dalam bait Alfiyyah itu sendiri. Nazm yang jika dibaca sekilas memang terkesan hanya berisikan materi kaidah saja, akan tetapi ketika dibaca lebih lanjut ternyata mengandung contohnya secara langsung. Maksudnya adalah redaksi teks kaidah dalam Alfiyyah terkadang menggunakan redaksi yang dapat dijadikan contoh dari kaidah yang sedang dibahas, isinya memang teori tetapi gaya bahasa pengungkapannya merupakan contohnya. Beliau mencontohkan bait pada bab al-Isytigāl yang berbunyi 'fa al-sābiq inșibhu bi fi'lin uḍirā * hatman muwāfiqin limā qad uzhirā "21. Secara sekilas teks tersebut memang berisi kaidah dalam pembuatan tarkīb al-Isytigāl, tetapi gaya bahasa penyampaiannya ternyata dengan menggunakan tarkīb al-Isytigāl. Maka dari itu sangat penting supaya Alfiyyah juga dipelajari secara tekstual maupun kontekstual. Penjelasan tersebut juga dikonfirmasi oleh AMIZ dan MDRN, santri kelas Alfiyyah II Pondok Pesantren Al-Luqmaniyyah.

Selain alasan tersebut, juga masih terdapat beberapa alasan lain, seperti: Paradigma utama yang dibangun adalah pemahaman tekstual

${ }^{21}$ Ibnu 'Aqīl, Syarḥ Ibn 'Aqīl 'Alā Al-Alfiyyah (Surabaya: Maktabah Imaratullah, 2015), 72. 
terlebih dahulu. Ketika pemahaman tekstual telah terpenuhi, maka pemahaman yang lain akan bisa dikembangkan; karena materi NaḥwuȘarf dari awal hingga akhir secara simultan selalu berkaitan; juga karena dapat dijadikan sebagai pengetahuan tambahan bagi santri bahwa jikalau Alfiyyah dikaji secara mendalam akan ditemukan pesanpesan moral di samping materi utamanya, yakni kaidah tata bahasa bahasa Arab.

Setelah ditelusuri lebih jauh lagi, pesan moral dan kandungan nilai yang dianggap menarik itu juga dapat dijumpai dalam Syarh Ibn 'Aqīl yang merupakan penjelasan dari kitab Alfiyyah Ibn Mālik. Menurut Sa'adatul, terdapat berbagai nilai karakter dalam kitab tersebut, di antaranya ialah nilai karakter agama, karakter pribadi, karakter bermasyarakat, dan karakter bernegara. ${ }^{22}$

Berkenaan dengan pembelajarannya, Komara menuturkan bahwa dalam kegiatan pembelajaran, tak jarang guru dan peserta didik menjumpai fenomena yang bersifat analogis atau memiliki persamaan, sehingga dalam prosesnya pun perlu dilakukan penalaran secara analogis. Penalaran secara analogis dalam pembelajaran ini dirasa penting untuk dilakukan karena upaya tersebut bisa meningkatkan kemampuan menalar pada peserta didik. Adapun cara yang bisa ditempuh ialah dengan membandingkan teori yang dikaji dengan materi lain yang memiliki persamaan dalam hal sifat esensialnya. ${ }^{23}$ Uraian tersebut setidaknya dapat mendukung alasan diimplementasikannya pembelajaran Naḥwu-Ṣarf kitab Alfiyyah Ibn Mālik dengan pendekatan interpretatif di Pondok Pesantren Al-Luqmaniyyah yang tidak menafikan adanya upaya penalaran secara analogis.

\section{Proses Pengimplementasian Pendekatan Interpretatif}

1. Interpretasi Tekstual dalam Pembelajaran

Interpretasi tekstual diartikan oleh Gracia sebagai sebuah penafsiran terhadap teks dengan cara menambahkan keteranganketerangan yang dipandang sangat penting untuk mendapatkan hasil tertentu di benak audiens kontemporer terkait teks tersebut. ${ }^{24}$

\footnotetext{
22 "Nilai-Nilai Karakter Dalam Syarah Alfiyyah Ibn 'Aqil Karya Imam Al-Alamah Syeikh Jalaluddin as-Suyuthi Dan Relevansinya Dengan Pendidikan Akhlak (Analisis Hermeneutik)" (Institut Agama Islam Negeri Ponorogo, 2020), 74.

${ }^{23}$ Endang Komara, Belajar Dan Pembelajaran Interaktif (Bandung: Refika Aditama, 2014), 99.

${ }^{24}$ Jorge J. E. Gracia, A Theory of Textuality: The Logic and Epistemology (New York: State University of New York Press, 1995), 164.
} 
Berdasar pengertian tersebut, Sahiron Syamsuddin menambahkan bahwa penafsiran tekstual merupakan upaya menangkap makna dari teks yang ditafsirkan (interpretandum). Interpretasi tekstual ini selain bertujuan untuk menangkap makna orisinal dari interpretandum, sebagaimana yang dimaksud oleh pengarang teks, juga bertujuan menciptakan makna baru yang dikreasi oleh interpreter dengan asumsi bahwa interpreter berperan dalam menciptakan makna, atau bertujuan menangkap implikasi dari makna teks tertentu. ${ }^{25}$

Berkenaan dengan pembelajaran Naḥwu-Ṣarf di Pondok pesantren Al-Luqmaniyyah, interpretasi tektual dalam pembelajaran Naḥwu-Șarf kitab Alfiyyah Ibn Mālik di Pondok Pesantren Al-Luqmaniyyah Yogyakarta terbagi dalam dua orientasi umum, yakni menggali makna asli teks dan menyampaikan makna orisinil yang dimaksud oleh pengarang.

Penggalian makna asli teks yang merupakan bagian dari proses interpretasi tekstual dalam pembelajaran Naḥwu-Șarf di Pondok Pesantren Al-Luqmaniyyah dilakukan melalui beberapa tahapan. Pemaknaan Jawa Pegon lengkap beserta tarkīb-nya bermanfaat untuk mengetahui makna setiap kata dan kedudukannya dalam suatu jumlah. Penjelasan tekstual oleh santri maupun ustaz untuk mengetahui substansi dari bait yang dikaji. Pemahaman makna teks per kata untuk mengetahui urutan pembacaan bait yang benar, karena sering ditemui nazm yang sengaja didahulukan dan diakhirkan maupun ditambah dan dikurangi untuk menyesuaikan wazn dan qäfiyah syair. Selain itu juga dapat diketahui bahwa dalam suatu teks teori ternyata menggunakan gaya bahasa yang dapat dijadikan contoh dari kaidah yang dipelajari.

Pemaknaan Jawa Pegon memang lazim digunanakan dalam pembelajaran kitab kuning di pesantren tradisional, tidak terkecuali dalam pembelajaran ilmu Naḥwu. Sebagaimana metode yang lain, metode ini juga memiliki kelebihan dan kekurangan. Kelebihannya ialah dapat memudahkan santri dalam mengetahui kedudukan kalimah dalam suatu jumlah, serta dan dapat menambah hafalan mufradāt bahasa Arab bagi pelajar. Sedangkan kekurangannya ialah dibutuhkan waktu yang lebih lama dalam pembelajaran, juga

${ }^{25}$ Hermeneutika Dan Pengembangan Ulumul Qur'an, 115. 
lebih berpotensi terjadinya kesalahan apabila kurang tepat dalam membaca kalimah dan memahami makna suatu kalimah. ${ }^{26}$

Kemudian pemahaman terhadap makna orisinil yang dimaksud oleh pengarang tentu menjadi acuan utama dalam pembelajaran Naḥwu-Ṣarf di kelas Alfiyyah II. Makna orisinil yang dimaksud oleh pengarang perlu dipahami supaya santri menguasai satu mazhab Nahwu terlebih dahulu sebelum mengenal mazhab yang lain dalam ilmu Nahwu. Selain makna orisinil yang dimaksud oleh mușannif juga dilakukan pemahaman ikhtilaf di antara ulama Nahwu berikut alasan atau latar belakang terjadinya ikhtilaf di antara ulama. Hal ini bertujuan supaya pemahaman santri lebih menyeluruh dan tidak gegabah merespons perbedaan pemahaman dalam ilmu Nahwu yang ada di hadapan mereka.

Mengingat bahwa kitab Alfiyyah Ibn Mālik merupakan kitab tata bahasa yang diperuntukkan bagi pembelajar bahasa Arab tingkat lanjut ${ }^{27}$, maka disebutkannya ikhtilaf atau perbedaan pendapat ulama ahli bahasa Arab dalam kitab tersebut merupakan hal wajar. Sebagaimanadimengerti bahwa dalam ilmun tata bahasa Arab terdapat lima mazhab besar, yakni golongan ulama Bashrah, Kuffah, Baghdad, Andalusia, dan Mesir. ${ }^{28}$ Karena hampir setiap bab tak ada yang luput dari penegasan Imam Ibnu Malik terkait perbedaan ulama, maka sudah sepantasnya jika kitab ini dipelajari secara mendalam sesuai dengan yang diharapkan oleh mușannif.

2. Interpretasi Nontekstual dalam Pembelajaran

Interpretasi nontekstual atau interpretasi nonliteral diartikan Gracia sebagai interpretasi yang tidak terpaku pada teks dan mempunyai tujuan lain, meskipun tujuan tersebut melibatkan-atau merupakan-semacam bentuk pemahaman, serta mungkin saja tetap disandarkan pada interpretasi tekstual. ${ }^{29}$

26 Nila Shefia, Mumtaz Tsaniatuz Zahroh Zamhuri, and Firda Nur Afifah, "Pemanfaatan Huruf Pegon Dalam Mempermudah Pembelajaran Nahwu," in Seminar Nasional Bahasa Arab (SEMNASMABA) V Tahun 2021 (Malang: HMJ Sastra Arab Fakultas Sastra Universitas Negeri Malang, 2021), 189. http://prosiding.arabum.com/index.php/semnasbama/article/view/783/731

27 Aliyah, "Pesantren Tradisional Sebagai Basis Pembelajaran Nahwu Dan Sharaf Menggunakan Kitab Kuning," Al-Ta'rib: Jurnal Ilmiah Program Studi Pendidikan Bahasa Arab IAIN Palangka Raya, Vol. 6 No. 1, 2018: 1-25. https://e-journal.iainpalangkaraya.ac.id/index.php/tarib/article/view/966

${ }^{28}$ Syauqī Daif, Al-Madāris Al-Naḥwiyyah (Cairo: Dār al-Ma'ārif, n.d.), 57.

${ }^{29}$ A Theory of Textuality: The Logic and Epistemology, 164-165. 
Syamsuddin menjelaskan bahwa interpretasi nontekstual tidak lagi berfungsi atau bertujuan menguak makna teks dan/atau implikasi sebuah teks sebagaimana yang dituju oleh interpretasi tekstual, melainkan lebih dalam lagi yakni mencoba menguak di balik makna tekstual. Interpretasi nontekstual tidak saja berinteraksi dengan makna dan implikasi makna teks yang dibaca atau $m \bar{a}$ fi al-nașs (apa yang ada di dalam teks), melainkan juga menguak dan memaparkan apa yang ada di sekitar teks (mā haula al-nașs). Sedangkan tujuannya adalah menciptakan pemahaman yang bukan hanya teks yang ditafsirkan, makna dan implikasinya, melainkan juga relasi teks dengan hal-hal lain. ${ }^{30}$

Berkenaan dengan pembelajaran Naḥwu-Șarf di Pondok pesantren Al-Luqmaniyyah, interpretasi nontektual dalam pembelajaran Naḥwu-Șarf kitab Alfiyyah Ibn Mālik di Pondok Pesantren Al-Luqmaniyyah juga terbagi dalam dua orientasi umum, yakni menguak kandungan di balik makna tekstual dan mencari relasi pemahaman teks terhadap hal lain.

Pembelajaran Naḥwu-Ṣarf kitab Alfiyyah Ibn Mālik di Pondok Pesantren Al-Luqmaniyyah sering kali disampaikan makna lebih mendalam yang terkandung di balik makna tekstualnya. Dengan arti lain, dapat dikatakan bahwa interpretasi kontekstual dilakukan dan disampaikan apabila dirasa ada makna di dalamnya dan perlu untuk disampaikan. Fleksibilitas sistem pembelajaran yang dilangsungkan dalam pembelajaran dapat menambah pengetahuan bagi santri supaya tidak hanya terpaku pada teks saja. Di samping dibekali supaya memahami teks secara mendalam, santri juga diberikan kesempatan untuk memahami konteks dari teks yang ada.

Pembelajaran semacam ini memang layak diimplementasikan, mengingat teks kitab Alfiyyah Ibn Mālik memang dapat digali makna filosofisnya. Bahkan setelah dikaji lebih mendalam ternyata di dalamnya terkandung berbagai nilai, seperti nilai agama, tanggung jawab, kejujuran, peduli sosial, kedisiplinan, cinta tanah air, kerja keras, sikap demokratis, kreativitas, dan kemandirian. ${ }^{31}$

\footnotetext{
${ }^{30}$ Hermeneutika Dan Pengembangan Ulumul Qur'an, 116.

${ }^{31}$ Muhamad Jaeni, “Tafsiran Kiai Pesantren Terhadap Bait-Bait Alfiyyah Ibn Malik Dan Transformasi Nilai Moral Santri: Kajian Intertekstual Dan Analisis Wacana Kritis," International Journal Ihya' 'Ulum Al-Din, Vol. 9 no. 2, 2017: 285-286. https://journal.walisongo.ac.id/index.php/ihya/article/view/2510
} 
Sedangkan kegiatan mengaitkan materi ilmu Naḥwu-Ṣarf yang sedang diperlajari di Pondok Pesantren Al-Luqmaniyyah dilakukan dengan beberapa hal, yaitu: (1) menghubungkan teks materi yang sedang dipelajari dengan materi atau bab lain dalam Naḥwu-Șarf; (2) mengaitkan materi Naḥwu-Șarf dengan ilmu kebahasaaraban lainnya; (3) membandingkan sifat esensial materi Naḥwu-Ṣarf dengan bahasa lainnya; serta (4) membandingkan sifat esensial materi Naḥwu-Ṣarf dengan cabang ilmu lain, bahkan dengan ilmu eksakta sekali pun.

Pengaitan materi Naḥwu dengan cabang keilmuan lain sebagaimana dimaksud di atas ini bukanlah hal yang baru, karena hal ini pernah dicontohkan oleh Imām al-Kisāī yang mengaitkan konsep ilmu Naḥwu-Ṣarf dengan fikih. Begawan Naḥwu dan sastra ini pernah berkata, "Man tabaḥhara fì ilm ihtadā bihi ilā sāir al"ulüm". Sebab pernyataan tersebut, Imām Abū Yūsuf mencoba mencari kebenarannya dan meminta Imām al-Kisāī untuk mencontohkan permasalahan fikih yang bisa dijawab dengan Naḥwu-Ṣarf. Lantas Imām al-Kisāī memberikan analogi tentang sujud syahwi yang ada dalam ilmu fikih dan dijawab dengan konsep bab Al-Tasgīr yang ada dalam ilmu Naḥwu-Șarf. ${ }^{32}$

Upaya pemaknaan ilmu bahasa Arab, termasuk ilmu NahwwuȘarf kitab Alfiyyah Ibn Mālik, yang dihubungkan dengan nilainilai kehidupan manusia memang dapat berkontribusi terhadap perkembangan ilmu pengetahuan itu sendiri. Bahkan cara pandang yang luas terhadap ilmu bahasa Arab juga dapat menjadi modal dalam menjaga kelangsungan ilmu bahasa Arab. ${ }^{33}$ Karena dengan cara tersebut, ilmu bahasa Arab tak lagi hanya diminati oleh pembelajar bahasa Arab saja, tetapi bisa lebih diminati oleh mereka yang memiliki antusiasme terhadap nilai-nilai kemanusiaan juga.

\section{Implikasinya Terhadap Pembelajaran Naḥwu-Șarf}

Penerapan pendekatan, metode, maupun strategi pembelajaran yang berbeda tentunya akan menghasilkan implikasi yang berbeda juga. Adapun pengimplementasian pendekatan interpretatif dalam pembelajaran Naḥwu-Ṣarf kitab Alfiyyah Ibn Mālik di Pondok

\footnotetext{
${ }^{32}$ Muhammad Nawawi bin Umar Al-Bantani, Qūt Al-Habīb Al-Garīb Tausyīkh 'alā Fatḥ Al-Qarīb Syarh Gāyah Al-Taqrīb (Beirut: Dār al-Kutub al-'Ilmiyyah, 2009), 137.

${ }^{33}$ Abd Aziz and Saihu, "Interpretasi Humanistik Kebahasaan: Upaya Kontekstualisasi Kaidah Bahasa Arab," Arabiyatuna: Jurnal Bahasa Arab, Vol. 3 No. 2, 2019: 299214. http://journal.iaincurup.ac.id/index.php/ARABIYATUNA/article/view/1000
} 
Pesantren Al-Luqmaniyyah ini berimplikasi pada peningkatan gairah santri dalam mengikuti kegiatan pembelajaran, serta penanaman nilainilai pengetahuan santri dalam kehidupan.

Pertama, meningkatkan gairah santri dalam mengikuti kegiatan pembelajaran. Pernyataan ini didasarkan pada temuan penelitan yang menunjukkan bahwa disampaikannya makna-makna implisit dalam teks pun dapat meningkatkan ketertarikan dan perhatian santri dalam mengikuti pembelajaran di kelas. Karena menurut mereka teks dalam Alfiyyah itu sering kali berkaitan dengan kondisi kehidupan yang dialami santri. Hal tersebut juga dapat memicu keinginan santri untuk belajar, sehingga proses jalannya pembelajaran pun menjadi semakin menarik.

Temuan tersebut sejalan dengan penjelasan Sutantik, bahwasanya pengungkapan unsur intrinsik dan ekstrinsik dalam pembelajaran bahasa dan sastra dapat meningkatkan minat minat peserta didik dalam mengikuti kegiatan pembelajaran. ${ }^{34}$

Kedua, menanamkan nilai-nilai pengetahuan santri dalam kehidupan. Pernyataan ini didasarkan pada temuan penelitian yang menunjukkan bahwa melalui pelajaran Naḥwu-Șarf sekali pun ternyata dapat memberikan implikasi terhadap penanaman nilai-nilai pengetahuan santri dalam kehidupanya. Sebagian nilai-nilai tersebut memang sudah dipraktikkan dalam kehidupannya, sebagian lagi masih sebatas pengetahuan dan belum terealisasikan, atau dengan kata lain belum dipraktikkan.

Sejalan dengan temuan tersebut, Muhid, Asnawi, dan Sa'dillah mengemukakan bahwa norma-norma yang sarat dengan kandungan akhlak dapat dijumpai melalui pembelajaran kitab Alfiyyah Ibn Mālik yang disertai dengan pemaknaan filosofis. Pengetahuan akhlak yang sekaligus diperoleh santri secara mendalam dalam pembelajaran Alfiyyah Ibn Mālik dapat mendorong santri untuk mengimplementasikannya dalam kehidupan sehari-hari. ${ }^{35}$

\footnotetext{
${ }^{34}$ Surati, "Peningkatan Pemahaman Unsur Intrinsik Dan Ekstrinsik Sastra Melalui Metode Presentasi Dan Diskusi," Dinamika: Jurnal Praktik Penelitian Tindakan Kelas, Vol. 6 No. 2, 2014: 66-75. http://i-

rpp.com/index.php/dinamika/article/view/443

${ }_{35}$ Abdul Muhid, Asnawi, Rangga Sa'adillah, "Pendidikan Moral Melalui Pembelajaran Kitab Alfiyyah Ibn Mālik Di Pondok Pesantren Langitan Tuban,” Jurnal Pendidikan Agama Islam: Journal of Islamic Education Studies, Vol. 6 No. 1 (2018): 106-126. http://jurnalpai.uinsby.ac.id/index.php/jurnalpai/article/view/177
} 


\section{Kesimpulan}

Berdasarkan uraian hasil penelitian dan pembahasan sebagaimana telah disebutkan di atas, dapat dimengerti bahwasanya pembelajaran dengan interpretatif benar-benar diterapkan proses pembelajaran Naḥwu-Ṣarf kitab Alfiyyah Ibn Mālik di Pondok Pesantren AlLuqmaniyyah Yogyakarta. Pendekatan interpretatif itu sejalan dengan teori interpretasi yang dikemukakan oleh Jorge JE Gracia karena terdapat proses interpretasi tekstual dan interpretasi nontekstual.

Alasan dipraktikannya pembelajaran Naḥwu-Șarf kitab Alfiyyah Ibn Mālik di Pondok Pesantren Al-Luqmaniyyah ialah karena pemahaman tekstual nazm sebagai paradigma utama dalam pembelajaran, penyimpangan dalam teks nazm Alfiyyah dari kaidah umum yang penting untuk diketahui, serta kandungan di balik makna tekstual maupun konsep kaidah yang menarik untuk diketahui.

Pembelajaran Nahwwu-Șarf kitab Alfiyyah Ibn Mālik di Pondok Pesantren Al-Luqmaniyyah melibatkan adanya proses proses interpretasi. Melalui pembelajaran interpretatif yang mengandung interpretasi tekstual dan interpretasi nontekstual itu, diperoleh bahwa: (1) penggalian makna asli dari teks yang dilakukan dengan pemaknaan Jawa Pegon dan pemahaman makna setiap kata; (2) makna asli yang dimaksud oleh pengarang teks menjadi acuan utama sebelum mendalami ikhtiläfiyyah yang ada; (3) penggalian makna batin di balik pemahaman tekstual dan konsep kaidah dilakukan dengan analisis mendalam setelah interpretasi tekstual telah tercapai; serta (4) pengaitan antara materi dengan hal lain dilakukan dengan membandingkan sifat esensial materi Naḥwu-Ṣarf kitab Alfiyyah Ibn Mālik dengan bahasa lainnya mapun dengan cabang ilmu lainnya. Selain itu juga dikaitkan antara bab yang sedang dipelajari dengan bab lainnya yang memang saling berkaitan.

Implikasi dipraktikannya pembelajaran Naḥwu-Ṣarf kitab Alfiyyah Ibn Mālik di Pondok Pesantren Al-Luqmaniyyah ialah meningkatknya gairah atau minat santri dalam mengikuti pembelajaran karena diperoleh pengetahuan baru melalui interpretasi nontekstual. Selain itu juga berimplikasi pada penanaman nilai-nilai pengetahuan santri dalam kehidupannya, meski sebagian nilai yang dijumpai ada yang sudah dilakukan dan ada yang belum dilakukan. 


\section{Daftar Pustaka}

'Aqīl, Ibnu. Syarh Ibn 'Aqūl 'Alā Al-Alfiyyah. Surabaya: Maktabah Imaratullah, 2015.

Abd Aziz and Saihu, "Interpretasi Humanistik Kebahasaan: Upaya Kontekstualisasi Kaidah Bahasa Arab," Arabiyatuna: Jurnal Bahasa Arab, Vol. 3, No. 2, 2019: 299-214. http://journal.iaincurup.ac.id/index.php/ARABIYATUNA/article/ view/1000

Abdul Muhid, Asnawi, Rangga Sa'adillah, "Pendidikan Moral Melalui Pembelajaran Kitab Alfiyyah Ibn Mālik Di Pondok Pesantren Langitan Tuban," Jurnal Pendidikan Agama Islam: Journal of Islamic Education Studies, Vol. 6, No. 1 (2018): 106-126. http://jurnalpai.uinsby.ac.id/index.php/jurnalpai/article/view/177

Adi Supardi, "Nilai-Nilai Karakter Pengguna Bahasa Arab Perspektif I'rab Nahwu," Kalamuna: Jurnal Pendidikan Bahasa Arab dan Kebahasaaraban, Vol. 2, No. 1, 2021: 37-49. https://ejurnal.staimuttaqien.ac.id/index.php/kalamuna/article/view/123

Afandi and Moh. Lutfi, "Membumikan Nilai-Nilai Akhlak Dalam Kitab Al-Fiyah Ibnu Malik Di Pondok Pesantren Roudlatul Mutaallimin Al Aziziyah II Sebaneh Bancaran Bangkalan," Attaqwa: Jurnal Ilmu Pendidikan Islam, Vol. 17, No. 2, 2021: 164-181.

https://jurnal.staidagresik.ac.id/index.php/attaqwa/article/view/157

Al-Bantani, Muhammad Nawawi bin Umar. Qūt Al-Habīb Al-Garīb Tausyīkh 'alā Fath Al-Qarīb Syarh Gāyah Al-Taqrīb. Beirut: Dār al-Kutub al-'Ilmiyyah, 2009.

Aliyah, "Pesantren Tradisional Sebagai Basis Pembelajaran Nahwu Dan Sharaf Menggunakan Kitab Kuning," Al-Ta'rib: Jurnal Ilmiah Program Studi Pendidikan Bahasa Arab IAIN Palangka Raya, Vol. 6 No. 1, 2018: 1-25. https://e-journal.iainpalangkaraya.ac.id/index.php/tarib/article/view/966

Al-Kūhani, Abd al-Qādir. Munyah Al-Faqīr Al-Mutajarrid Wa Sīrah Al-Murīd Al-Mutafarrid. Aleppo: Dār al-Hayāh, n.d.

Al-Mirzanah, Syafa'atun, and Sahiron Syamsuddin, eds. Pemikiran Hermeneutika dalam Tradisi Barat: Reader. Yogyakarta: Lembaga Penelitian UIN Sunan Kalijaga, 2011.

Al-Qusyairī, Abd al-Karīm ibn Hauzan ibn 'Abd al-Mālik ibn Țalḥah ibn Muhammad Abū al-Qāsim. Naḥwu Al-Qulūb. Beirut: Dār alKutub al-'Ilmiyyah, 2005. 
Ḍaif, Syauqī. Al-Madāris Al-Naḥwiyyah. Cairo: Dār al-Ma'ārif, n.d.

Fatkhiyyaa Izza Khunainatuz and Hilyah Ashoumi, "Analisis NilaiNilai Pendidikan Islam Yang Terkandung Dalam Makna Tersirat Nadzam Alfiyah Ibnu Malik Dan Aktualisasinya Pada Konteks Pendidikan Islam Modern," Jurnal Ilmu Pendidikan Islam, Vol. 16, No. 1, 2020: 1-14. https://jurnal.staidagresik.ac.id/index.php/attaqwa/article/view/33

Gracia, Jorge J. E. A Theory of Textuality: The Logic and Epistemology. New York: State University of New York Press, 1995.

Gufron, Arif Mustofa, and Abdullah Zainur Rauf, "Interpretasi Dan Aktualisasi Nilai-Nilai Etika Nadham Alfiyah Ibnu Malik Dalam Kehidupan Sosial (Pendekatan Obyektif Pragmatik)," Arabia: Jurnal Pendidikan Bahasa Arab, Vol. 12, No. 1, 2020: 54-73. https://journal.iainkudus.ac.id/index.php/Arabia/article/view/7439

Huda, Rizki Fathul, Iik Arifin Mansurnoor, and Andi M. Faisal Bakti. "The Concept of Sufi I'rab by Abdul Qadir Al-Kuhany in Understanding the Salat Movement." In Proceedings of the 2nd International Colloquium on Interdisciplinary Islamic Studies (ICIIS) in Conjunction with the 3rd International Conference on Quran and Hadith Studies (ICONQUHAS). Bratislava: EAI, 2020. Iman, Nur. Al-Sunī Al-Mațālib F̄̄ Al-Iștilāh Al- 'Awāqib, n.d.

Kaḥālah, Umar Rị̣ā. Mu'jam Al-Muallifìn. Beirut: Muassasạ̣ alRisālah, 1993.

Khoiriyah, Miftah Sa'adatul. "Nilai-Nilai Karakter dalam Syarah Alfiyyah Ibn 'Aqil Karya Imam Al Alamah Syeikh Jalaluddin AsSuyuthi Dan Relevansinya dengan Pendidikan Akhlak (Analisis Hermeneutik).” Institut Agama Islam Negeri Ponorogo, 2020.

Komara, Endang. Belajar Dan Pembelajaran Interaktif. Bandung: Refika Aditama, 2014.

Masduqi, Irwan. Suluk Sufi Ulama Karaton Yogyakarta: Ajaran Kyai Nur Iman. Yogyakarta: Assalafiyah Press, 2011.

Muhamad Jaeni, “Tafsiran Kiai Pesantren Terhadap Bait-Bait Alfiyyah Ibn Malik Dan Transformasi Nilai Moral Santri: Kajian Intertekstual Dan Analisis Wacana Kritis," International Journal Ihya' 'Ulum Al-Din, Vol. 9, No. 2, 2017: 285-286. https://journal.walisongo.ac.id/index.php/ihya/article/view/2510

Muhammad Iqbal Maulana, "Refleksi Sufistik Dalam Nahwu Al-Qulub Karya Abu Al-Qasim Al-Qusyairi," Dialogia: Jurnal Studi Islam dan Sosial, Vol. 17, No. 1, 2019: 21-40. 
ALIBBAA': Jurnal Pendidikan Bahasa Arab, 3 (1), 2022

https://jurnal.iainponorogo.ac.id/index.php/dialogia/article/view/1 654

Mujahadah, "Dimensi Sufistik Dalam Ilmu Nahwu: Studi Komparatif Antara Kitab Nahwu Al-Qulub Karya Al-Qusyairi Dan Munyah Al-Faqir Al-Mutajarrid Wa Sirah Al-Murid Al-Mutafarrid Karya Al-Kuhany" (Universitas Islam Negeri Antasari, 2021), http://idr.uin-antasari.ac.id/16938/.

Sa'adatul, Miftah. "Nilai-Nilai Karakter dalam Syarah Alfiyyah Ibn 'Aqil Karya Imam Al-Alamah Syeikh Jalaluddin as-Suyuthi dan Relevansinya dengan Pendidikan Akhlak (Analisis Hermeneutik)." Institut Agama Islam Negeri Ponorogo, 2020.

Sahiron Syamsuddin, Hermeneutika Dan Pengembangan Ulumul Qur'an (Yogyakarta: Pesantren Nawasea Press, 2017), 114; Ulummudin, "Hadith on the Prohibition of Woman Traveling without a Mahram (Application of Hermeneutic Theory of Jorge J. E. Gracia)," Asliha-Islamicate Institute: Journal of Hadith Studies, Vol. 1, No. 1, 2018: 29-30. https://journal.islamicateinstitute.co.id/index.php/johs/article/view 1361

Shahrizal Mahpol, Muhammad Saiful Anuar Yusoff, and Muhammad Luqman Ibnul Hakim, "Nilai Kerohanian Dalam Disiplin Ilmu Nahu; Kajian Terhadap Sumbangan Al-Qushayri," INSANIAH: Online Journal of Language, Communication, and Humanities, Vol. 3, No. 1, 2020: 12-25. http://insaniah.umk.edu.my/journal/index.php/insaniah/article/vie $\underline{w} / 68$

Shefia, Nila, Mumtaz Tsaniatuz Zahroh Zamhuri, and Firda Nur Afifah. "Pemanfaatan Huruf Pegon dalam Mempermudah Pembelajaran Nahwu." In Seminar Nasional Bahasa Arab (SEMNASMABA) V Tahun 2021, 189-201. Malang: HMJ Sastra Arab Fakultas Sastra Universitas Negeri Malang, 2021. http://prosiding.arabum.com/index.php/semnasbama/article/view/783/731

Sukmadinata, Nana Syaodih. Metode Penelitian Pendidikan. Bandung: PT Remaja Rosdakarya, 2007.

Surati, "Peningkatan Pemahaman Unsur Intrinsik Dan Ekstrinsik Sastra Melalui Metode Presentasi Dan Diskusi," Dinamika: Jurnal Praktik Penelitian Tindakan Kelas, Vol. 6, No. 2, 2014: 66-75. http://i-rpp.com/index.php/dinamika/article/view/443

Syamsuddin, Sahiron. Hermeneutika dan Pengembangan Ulumul Qur'an. Yogyakarta: Pesantren Nawasea Press, 2017. 
ALIBBAA' : Jurnal Pendidikan Bahasa Arab, 3 (1), 2022

Widodo, Sembodo Ardi. "Metode Hermeneutik dalam Pendidikan." In Antologi Pendidikan Islam, edited by Nizar Ali and Sumedi, 31:95-110. Yogyakarta: Idea Press, 2010.

Zakiyah, "Kitab Al-San̄̄ Al-Mațālib: Interkoneksi Nahwu Dan Tasawuf," Walisongo: Jurnal Penelitian Sosial Keagamaan, Vol. 20, No. 2, 2012: 371-390. https://journal.walisongo.ac.id/index.php/walisongo/article/view/ 204

Zamzam Afandi and Arief Rahman Hakim, "Al-Takwīl Al-Bāținī Li Musțalahāt an-Nahwi (Takamul Al-Tasawwuf Wa Al-Nahwi)," LiNGUA: Jurnal Ilmu Bahasa dan Sastra, Vol. 16, No. 1, 2021: 99-110.

https://ejournal.uinmalang.ac.id/index.php/humbud/article/view/12242 